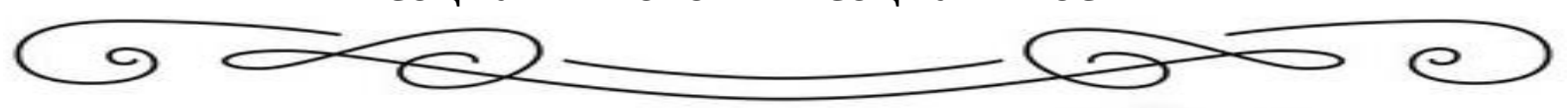

МОЛОДІЖНА РОБОТА

удк 351:352.455

DOI: 10.31499/.3.2019.190413

\title{
НОРМАТИВНО-ПРАВОВЕ РЕГУЛЮВАННЯ СОЦІАЛЬНОЇ РОБОТИ З МОЛОДДЮ
}

Ісаченко Вікторія, кандидат педагогічних наук, доцент кафедри соціальної педагогіки та соціальної роботи, Уманський державний педагогічний університет імені Павла Тичини.

ORCID: 0000-0002-9072-8788

E-mail: viki.isachenko@gmail.com

у статті наведено стислий аналіз різних підходів до визначення поняття «молодь» $у$ нормативно-правових актах України та світу. Проведено порівняння підходів до визначення вікових меж молоді. Розглянуто соціальну роботу як специфічний вид професійної діяльності. Проаналізовано молодіжні цільові програми як дієвий інструмент реалізації молодіжної політики України. З'ясовано, що сучасний стан соціальної роботи з молоддю являє собою систему законодавчих і нормативних актів, організаційних заходів і заходів із встановлення та підтримки соціального статусу молодого покоління.

Ключові слова: молодь, молодіжна політика, нормативно-правові акти, вікові межі молоді, соціальна робота, молодіжні цільові програми, реалізації молодіжної політики, формування готовності молоді до діяльності в сфері молодіжної політики.

\section{LEGAL REGULATION OF SOCIAL WORK WITH YOUTH}

Isachenko Viktoriia, $\mathrm{PhD}$ in Pedagogical Sciences, Associate Professor of the Department of Social Pedagogy and Social Work, Pavlo Tychyna Uman State Pedagogical University.

ORCID: 0000-0002-9072-8788

E-mail: viki.isachenko@gmail.com

A brief analysis of different approaches to defining the concept of "youth" in the normative legal acts of Ukraine and the world is given. The approaches to determining the age limits of young people are compared. Social work is considered as a specific type of professional activity. Youth target programs have been analyzed as an effective tool for the implementation of Ukraine's youth policy. The basic provisions of youth policy are considered. Prospects for further elaboration of the problem of forming of youth readiness for activity in the sphere of youth policy are defined. It is revealed that the current state of social work with young people is a system of legislative and regulatory acts, organizational measures and measures for establishing and maintaining the social status of the young generation, which is a specific activity of the authorities.

The excursion made to the problem of defining clear boundaries of youth age makes it possible to state the difficulties in determining the age characteristics of youth as an object of social work, which in turn causes complexity in the adaptation of best international practices to modern social work in Ukraine.

To solve most problems of a young person it is enough to get in time a specialist's advice on an 


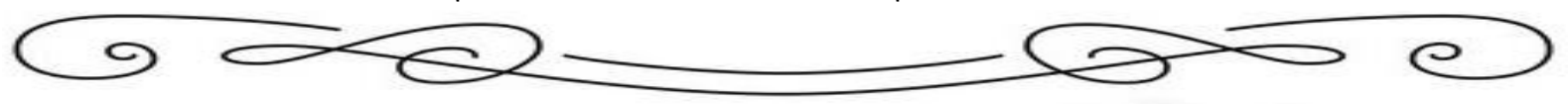

exciting topic.

The current state of social work with young people is a system of legislative and regulatory acts, organizational measures and measures for establishing and maintaining the social status of the young generationl. It is a specific activity of the authorities aimed at supporting the normative life of children, adolescents and young people in modern society.

Keywords: youth, youth policy, regulations, youth age limits, social work, targeted youth programs, implementation of youth policy, formation of youth readiness for activities in the field of youth policy.

Для сучасної України одним із найважливіших завдань $є$ громадянське, національно-патріотичне виховання дітей та молоді, їх залучення до соціальнополітичних та економічних перетворень, процесу інтеграції України до світової спільноти. Поняття «молодь» має стійкий асоціативний зв'язок з нововведеннями та інноваціями. Їй відводиться пріоритетна роль владного агента політичних, економічних, культурних змін в суспільстві. Нині актуальним $\epsilon$ наукове вивчення сучасних молодіжних практик. Оптимізація процесу становлення молоді як самостійного суб'єкта соціальних відносин $є$ предметом соціальної роботи.

Теоретичний огляд молоді як суб'єкта державотворчих процесів здійснено у праці В.В. Мотречко. Автором проведено порівняння підходів до визначення вікових меж індивіда. Розглянуто питання, що пов'язані з етапами соціалізації молоді. Запропоновано механізм взаємодії суспільства і молоді через їі соціалізацію [9].

Відображення дослідження молодіжних цільових програм знаходимо у статті С. С. Гринчишина. Автором виокремлено п'ять основних періодів розвитку молодіжної політики в Україні та проаналізовано динаміку загального обсягу фінансування реалізації програми «Молодь України» на 2016-2020 роки [4, с. 140].

Аналіз прогалин законодавства України щодо молодіжної політики в контексті рекомендацій угоди про асоціацію між Україною та ЄС здійснено Центром прав дитини Корам (Coram Children's Legal Centre), результатом якого став оприлюднений звіт Кірстен Андерсон [1, с. 4].

Конструктивно-критичний аналіз молодіжної політики України, рекомендації до загальної стратегії сприяння розвитку молодіжної політики знаходимо в посібнику команди міжнародних оглядачів Ради Європи Видавництва Ради Європи «Молодіжна політика в Україні» [5, с. 7].

Метою статті $\epsilon$ визначення поняття «молодь» та особливостей удосконалення окремих напрямів державної цільової молодіжної політики України.

Соціальна робота з молоддю - специфічний вид професійної діяльності, спрямований на життєзабезпечення молодого покоління, що здійснюється державними, регіональними, муніципальними, а також комерційними та громадськими організаціями, окремими громадянами [2, с. 65]. Цей вид діяльності включає в себе комплекс правових, соціально-медичних, економічних, психологічних, педагогічних, організаційно-профілактичних, інформаційних та інших заходів щодо запобігання негативних явищ в соціальному середовищі підростаючого покоління, а також формування суспільно-значущих властивостей молодого покоління відповідно до стратегічних орієнтирів розвитку соціуму. 


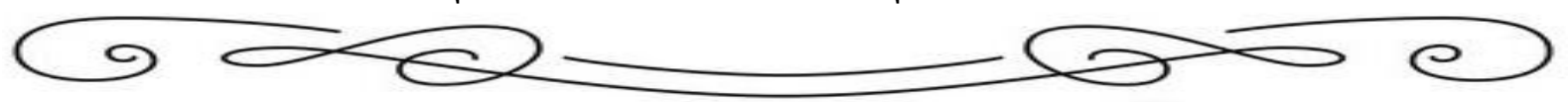

Характерною особливістю соціальної роботи 3 молоддю $є$ залучення самих молодих людей до соціальних заходів.

Закон України «Про соціальну роботу з сім'ями, дітьми та молоддю» визначає соціальну роботу з молоддю - як діяльність уповноважених органів, підприємств, організацій та установ, що здійснюють соціальну роботу з сім'ями, дітьми та молоддю, а також фахівців з соціальної роботи та волонтерів, яка спрямована на соціальну підтримку сімей, дітей та молоді, забезпечення їхніх прав і свобод, поліпшення якості життєдіяльності, задоволення інтересів та потреб [6].

Соціальна робота з молоддю відрізняється складністю чіткого визначення об'єкта їі діяльності. По-перше, через відсутність чіткого визначення вікових меж молоді як соціально-демографічної групи, які історично і соціально обумовлені. Встановлення вікових меж завжди умовно та індивідуально, а також залежить від географічних, регіональних, національних, історико-культурних (традиції і звичаї народів) і навіть політичних чинників.

Згідно з Законом України «Про сприяння соціальному становленню та розвитку молоді в Україні», молодь, молоді громадяни - це громадяни України віком від 14 до 35 років [7].

Потрібно підкреслити, що визначення поняття «молодь» у ключових законодавчих актах та стратегіях в Україні суттєво відрізняється від підходів у світовій практиці.

Організація Об'єднаних Націй $(\mathrm{OOH})$ використовує універсальне визначення поняття «молодь», яке було запропоноване Всесвітньою організацією охорони здоров'я раніше, та визначає,що це особи віком від 15 до 24 років [15].

Всесвітня організація охорони здоров'я у 2017 році офіційно переглянула вікові норми. I тепер молодою людина вважається від 25 до 44 років [14].

ЮНЕСКО для забезпечення соціальної роботи з молоддю на міжнародному рівні використовує універсальне визначення ООН, та визначає вікові межі юридично закріплені у конкретній державі [16].

ЮНІСЕФ як і інші агенції системи ООН користується у своїй роботі першим визначенням В0О3 щодо віку, а саме: «Молодь»- особи віком від 15 до 24 років [12].

У той же час Конвенція ООН про права дитини визначає, що до 18-річного віку кожна людська істота визначається як дитина (якщо вона не досягає повноліття раніше) [8].

Отже, відповідно до підходу ПРООН у рамках теоретичного аналізу поняття «молодь» $є$ відносно гнучким.

Широкі вікові межі (від 14 до 35 років) можуть призвести до розпорошення програм та фінансування серед груп молоді (молоді різного віку). Крім того, вони розглядаються як свідчення патерналістського характеру молодіжної політики, що проявляється у намаганнях контролювати та направляти розвиток молодих людей протягом якомога довшого періоду [5, с. 7].

Зроблений екскурс в проблему визначення чітких меж віку молоді дозволяє констатувати труднощі у визначенні вікових характеристик молоді як об’єкта 


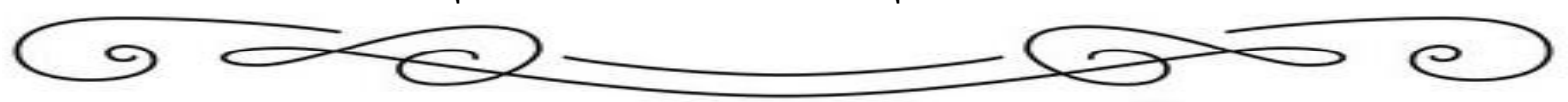

соціальної роботи, що в свою чергу зумовлює складність в адаптації найкращих міжнародних практик у сучасну соціальну роботу в Україні.

Соціальне обслуговування молоді як частина соціальної політики держави $\epsilon$ цілісною системою, яка знаходиться в постійній взаємодії 3 регіональними умовами молодіжного середовища. Взаємодія системи і середовища здійснюється за допомогою їх взаємного впливу.

Значущим у сфері сприяння розвитку та становленню соціальної, громадської зрілості молоді $є$ Державна цільова соціальна програма «Молодь України» на 2016-2020 роки, яка базується на необхідності повноцінного розвитку та самореалізації молоді, що $\epsilon$ однією із суспільних цінностей, а соціальна підтримка молоді $\epsilon$ одним 3 основних пріоритетів державної політики [11].

Програма регламентує європейські засади розвитку молодіжної політики побудована з урахуванням вікових меж молоді від 14 до 35 років включно, у тому числі дітей віком від 14 до 18 років [11].

Цей законодавчий документ передбачає сприяння у розв'язанні таких проблем як: формування у молодих людей громадянської позиції та національнопатріотичної свідомості; низький рівень зайнятості молоді на ринку праці за обраною професією; складність та тривалість переходу молоді від навчання до стабільної та задовільної роботи; повільні темпи розвитку підприємництва серед молоді; високий рівень захворюваності та смертності молоді, слабка мотивація до дотримання молодими людьми здорового i безпечного способу життя, недостатній рівень знань та навичок молоді у галузі безпеки життєдіяльності; відсутність сталої тенденції до зниження рівня злочинності у молодіжному середовищі, насильства та системної роботи у сфері їх профілактики; низький рівень забезпечення молодих сімей житлом; низький рівень організації та культури молодіжного дозвілля; слабка інтегрованість української молоді у європейське та світове молодіжне співтовариство [11].

Щодо покращення соціально-політичного становища молоді в Україні одним 3 найвагоміших кроків стала розробкою молодіжної стратегії ООН: «Молодь 2030». Мета стратегії покликана сприяти посиленню впливу i нарощування масштабів зусиль, прикладених на глобальному, регіональному і країновому рівні з метою задоволення потреб молоді, зміцнення потенціалу та розширення прав молоді в усьому їі різноманітті по всьому світу, а також забезпечити їі участь у здійсненні та огляді Порядку денного на період до 2030 року та інших повісток і рамкових документів і в прийнятті наступних заходів у зв'язку з ними [16].

Національна молодіжна рада України прагне створити в Україні середовище, в якому права кожної молодої людини будуть дотримані, у всіх молодих людей буде можливість у повній мірі розкрити свій потенціал у професійній та особистій сфері. Для створення цього середовища необхідно враховувати, що життя молодих людей визначається політикою у різноманітних сферах та на різних рівнях її реалізації [10].

Отже, лише шляхом включення молоді як пріоритету серед різних сфер 


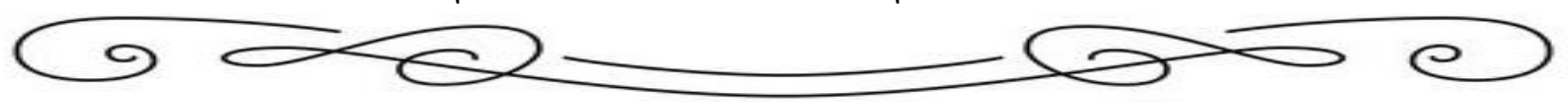

політики, можна забезпечити врахування конкретних потреб молодих людей у політиці держави чи програмах, що стосуються молоді. Рекомендації до Стратегії розвитку державної молодіжної політики на період до 2030 року передбачають посилення міжгалузевого співробітництва на всіх рівнях прийняття рішень та синергію і взаємодоповнюваність між молодими людьми, органами місцевого самоврядування, органами виконавчої та державної влади [10].

Стратегія формує основні принципи та пріоритети для співпраці в рамках молодіжної політики всіх зацікавлених сторін. Серед пунктів: 1) участь молоді у процесі прийняття рішень; 2) залучення молоді до політичного процесу; 3) безпека та екологія; 4) формальна та неформальна освіта; 5) гендерна рівність; 6) інклюзія та права людини; 7) здоров'я молоді; 8) економічна інтеграція молоді: підприємництво і працевлаштування; 9) доступ до інформації; 10) підвищення мобільності молоді і культурна дипломатія; 11) молодіжна робота і волонтерство; 12) молодіжне житло та інфраструктура; 13) молодіжна політика в умовах децентралізації; 14) молодь і культура [13].

Для визначення найбільш актуальних та перспективних напрямків соціальної роботи з молоддю нами проведено дослідження інтересів, потреб і очікувань молодих людей. За весь період було опитано 135 осіб в закладах освіти м. Умань методом випадкової вибірки.

Питання стосувалися різних сфер життя: дозвілля, навчання, політики, спорту, побутових проблем. У числі найважливіших тем значилися і питання соціального захисту молодого покоління. Зупинимося лише на тих критеріях, які найбільше, на нашу думку, потребують соціального втручання.

Згідно з отриманими результатами, 78 \% молодих людей володіють інформацією про наявність соціальних організацій, які могли б надати їм допомогу і підтримку в можливих несприятливих ситуаціях або надати необхідну інформацію, в той же час 12 \% взагалі не мають уявлення про служби соціальнопсихологічної підтримки. Більшою чи меншою мірою молоді люди обізнані про наявність психологічних служб: телефон довіри, кризові центри, служби анонімної допомоги та ін.

Найчастіше молоді люди обходяться допомогою найближчого соціального оточення (друзі, сім'я - 76 \%) або справляються (успішно, чи ні) самостійно (31\% респондентів). 3 одного боку, це може свідчити про те, що у молоді немає «проблем», з якими вони не можуть самі впоратися, або що вони цілком самостійні і добре поінформовані. 3 іншого, це може свідчити, що сфера молодіжної політики характеризується наявністю певної ізольованості, як в силу специфіки особливостей, та складної кризової ситуації в країні.

На перше місце серед проблем, що хвилюють молоде покоління виходять психологічні - ними стурбовані $35 \%$ опитуваних. Крім того, серед основних проблем молоді люди виділяють також економічні (нестача коштів на життя, навчання, дозвілля) і побутові (необлаштованість житла або його відсутність).

Найважливішими соціальними молодіжними проблемами є: зловживання алкогольними напоями (17\% зовсім не вживають алкоголь, $52 \%$ опитаних вживає міцні спиртні напої «на свята», 29 \% п'ють слабоалкогольні напої майже 


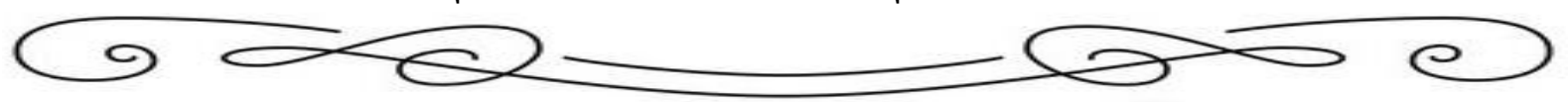

кожен день), тютюнопаління (постійно палять $41 \%$, «не часто» - $14 \%$, зовсім не палять 38 \%, кинули цю згубну звичку 9 \%). Варто зазначити, що більшість молоді не вважають свої шкідливі звички «проблемою».

Позитивною динамікою позначається прагнення молоді до здорового способу життя: $19 \%$ респондентів ведуть «активний здоровий спосіб життя»; $31 \%$ - намагаються дотримуватися такого способу життя, 21 \% «дуже хотіли б, але поки не вдавалося». Більше 30 \% опитаних регулярно (або хоча б періодично) відвідують різні спортивні секції, спорт-клуби, басейн, а майже половина активно проводить своє дозвілля: грають з друзями в футбол, катаються на роликах, лижах, велосипеді тощо. Варто, зауважити, що за останні роки різко скоротилася кількість безкоштовних гуртків, секцій для молоді, а платні багатьом недоступні.

Готовність молоді до діяльності в сфері соціальної молодіжної політики виявили високий рівень - 7,8\%, середній - 40,1\%, низький 52,1\%. Отримані результати дослідження відкривають перспективи для подальшої розробки проблеми формування готовності молоді до діяльності в сфері молодіжної політики.

Молодь в силу специфіки свого віку відрізняється вираженим прагненням до чогось нового, до пізнання, об'єднання, спілкування зі своїми однолітками. Більшість респондентів хотіли б відвідувати секції за інтересами, здобувати додаткову освіту, займатися спортом. Деякі юнаки та дівчата готові брати активну участь в житті міста, свого району, допомагати в облаштуванні своїх прибудинкових територій, будинків, під'їздів, але не знають: як їм це зробити, куди слід звертатися з подібними ініціативами?

В силу об'єктивних причин (недостатності життєвого досвіду) у молоді велика потреба в різного роду консультаційних службах, перш за все - 3 психологічних питань (консультацію психолога хотіли б отримати $40 \%$ ), юридичним і медико-сексуальних питань (27 \% і 20 \%, відповідно).

Для вирішення більшості проблем молодої людини досить лише вчасно отримати консультацію фахівця 3 хвилюючою теми. Втручання соціального працівника потрібно тоді лише в крайніх випадках, коли проблема набула затяжного кризового характеру. у такій ситуації молода людина вже не може самостійно (або за допомогою найближчого оточення) вийти 3 кризового становища, їй потрібна допомога фахівця.

Завдання соціальних працівників, які надають допомогу представникам молодого покоління, полягає в тому, щоб «молодіжні» проблеми не переходили в розряд нерозв'язних ситуацій. Фахівці повинні подбати про те, щоб заздалегідь забезпечити дітей, юнаків та дівчат необхідною життєво важливою інформацією, яка допомогла б їм в подоланні проблемних ситуацій.

3 цією метою бажано було б створити велику мережу консультаційних пунктів для молоді, в яких діти, підлітки та молоді люди могли отримувати необхідну для них інформацію. Причому консультації повинні надаватися за різними життєво важливими сферами особистості: медицини, психології, юриспруденції, освіти та ін. 


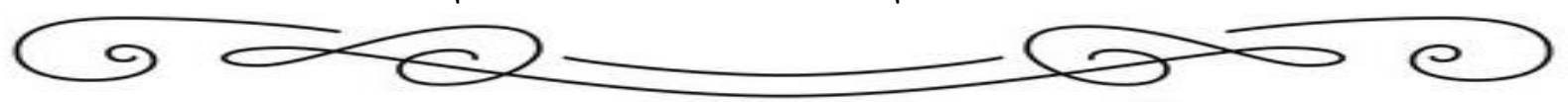

Таким чином, соціальна робота повинна не тільки захищати молоде покоління, а й готувати молодь до самостійного життя, формувати у неї позитивні якості, необхідні для вирішення соціально-економічних проблем нашої держави в майбутньому. Сучасний стан соціальної роботи з молоддю являє собою систему законодавчих i нормативних актів, організаційних заходів i заходів із встановлення та підтримки соціального статусу молодого покоління, це специфічна діяльність органів влади, спрямована на підтримку нормативного життєзабезпечення дітей, підлітків та молоді в сучасному суспільстві. Ефективність проведеної державою такої політики визначає якість підростаючого покоління, ступінь його відповідності необхідним стандартам для реалізації стратегії розвитку країни на середньострокову і довгострокову перспективи.

\section{СПИСОК ВИКОРИСТАНИХ ДЖЕРЕЛ}

1. Андерсон К. Аналіз прогалин законодавства України про молодіжну політику в контексті рекомендацій угоди про асоціацію між Україною та ЄС й іншими відповідними політичними документами ЄС. Київ: Центр Прав Дитини Корам (Coram Children’s Legal Centre), 2017. 89 с.

2. Безпалько О.В. Організація соціально-педагогічної роботи 3 дітьми та молоддю у територіальній громаді: теоретико-методичні основи: монографія. Київ: Наук. світ, 2006. 363 с.

3. Гринчишин С. С. Молодіжні цільові програми як дієвий інструмент реалізації молодіжної політики в Україні. Інвестиції: практика та досвід. 2019. С. 140-144.

4. Кжаклевска Е., Вільямсон Г. Молодіжна політика в Україні. Висновки Команди міжнародних оглядачів Ради Європи. Київ: Департамент підготовки документів та публікацій Ради Європи, 2018. 192 с.

5. Про соціальну роботу 3 сім'ями, дітьми та молоддю: закон України. URL: https://zakon.rada.gov.ua/laws/show/2558-14.

6. Про сприяння соціальному становленню та розвитку молоді в Україні: Закон України. URL: https://zakon3.rada.gov.ua/laws/show/2998-12.

7. Конвенція про права дитини. URL: https://zakon.rada.gov.ua/laws/show/995_021

8. Мотречко В.В. Молодь як суб'єкт державотворчих процесів: теоретичні засади. URL: http://www.kbuapa.kharkov.ua/e-book/apdu/2014-2/doc/7/04.pdf.

9. Рекомендації Національної молодіжної ради України до Стратегії розвитку державної молодіжної політики на період до 2030 року. Національна молодіжна рада України. 2019. URL: http://nycukraine.org/wp-content/uploads/2019/03/Strategiya-molodizhnoyi-politiki-2030-2.pdf.

10. Про схвалення Концепції Державної цільової соціальної програми «Молодь України» на 20162020 роки: Розпорядження Кабінету Міністрів України. URL: https://www.kmu.gov.ua/ ua/npas/248528402.

11. Становище дітей в світі, 2019 рік: звіт. UNICEF. 2019. URL: https://www.unicef.org/ukraine/uk.

12. Про Стратегію розвитку державної молодіжної політики на період до 2020 року: указ Президента України. URL: https://zakon.rada.gov.ua/laws/show/532/2013.

13. Publications news. WHO Regional Office for Europe. 2017. URL: http://www.euro.who.int/en/home.

14. World Programme of Action for Youth. Department of Economic and Social Affairs Youth. 2019. URL: https://www.un.org/development/desa/youth/world-programme-of-action-for-youth.html.

15. Youth 2030 the United Nations Youth Strategy. Envoy on Youth. 2019. URL: https://www.un. org/youthenvoy/2013/08/unesco-united-nations-educational-scientific-and-cultural-organization/

\section{REFERENCES}

1. Anderson, K. (2017). Analiz prohalyn zakonodavstva Ukrainy pro molodizhnu polityku v konteksti rekomendatsii uhody pro asotsiatsiiu mizh Ukrainoiu ta YeEs i inshymy vidpovidnymy politychnymy dokumentamy YeEs. Kyiv: Tsentr Prav Dytyny Koram (Coram Children’s Legal Centre) [in Ukrainian]. 


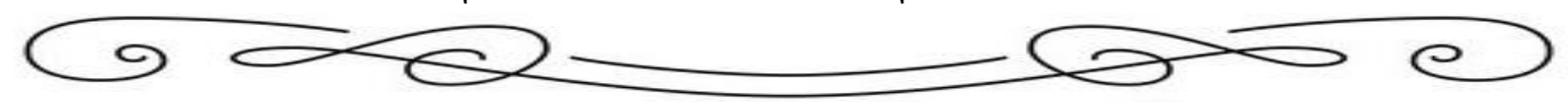

2. Bezpalko, O.V. (2006). Orhanizatsiia sotsialno-pedahohichnoi roboty $\mathrm{z}$ ditmy ta moloddiu u terytorialnii hromadi: teoretyko-metodychni osnovy. Kyiv: Nauk. Svit [in Ukrainian].

3. Hrynchyshyn, S.S. (2019). Molodizhni tsiliovi prohramy yak diievyi instrument realizatsii molodizhnoi polityky v Ukraini. Investytsii: praktyka ta dosvid, 140-144 [in Ukrainian].

4. Kzhaklevska, E. Viliamson, H. (2018). Molodizhna polityka v Ukraini. Vysnovky Komandy mizhnarodnykh ohliadachiv Rady Yevropy. Kyiv: Departament pidhotovky dokumentiv ta publikatsii Rady Yevropy [in Ukrainian].

5. Pro sotsialnu robotu $\mathrm{z}$ simiamy, ditmy ta moloddiu: zakon Ukrainy. URL: https://zakon.rada.gov.ua/laws/show/2558-14 [in Ukrainian].

6. Pro spryiannia sotsialnomu stanovlenniu ta rozvytku molodi v Ukraini: zakon Ukrainy. URL: https://zakon3.rada.gov.ua/laws/show/2998-12 [in Ukrainian].

7. Konventsiia pro prava dytyny. URL: https://zakon.rada.gov.ua/laws/show/995_021[in Ukrainian].

8. Motrechko, V.V. (2019). Molod yak subiekt derzhavotvorchykh protsesiv: teoretychni zasady. URL: http://www.kbuapa.kharkov.ua/e-book/apdu/2014-2/doc/7/04.pdf [in Ukrainian].

9. Rekomendatsii Natsionalnoi molodizhnoi rady Ukrainy do Stratehii rozvytku derzhavnoi molodizhnoi polityky na period do 2030 roku. (2019). Natsionalna molodizhna rada Ukrainy. URL: http://nycukraine.org/wp-content/uploads/2019/03/Strategiya-molodizhnoyi-politiki-2030-2.pdf [in Ukrainian].

10. Pro skhvalennia Kontseptsii Derzhavnoi tsilovoi sotsialnoi prohramy "Molod Ukrainy" na 20162020 roky: rozporiadzhennia Kabinetu Ministriv Ukrainy. URL: https://www.kmu.gov.ua/ua/ npas/248528402 [in Ukrainian].

11. Stanovyshche ditei v sviti, 2019 rik: zvit. (2019). UNICEF. URL: https://www.unicef.org/ukraine/uk [in Ukrainian].

12. Pro Stratehiiu rozvytku derzhavnoi molodizhnoi polityky na period do 2020 roku: ukaz Prezydenta Ukrainy. URL: https://zakon.rada.gov.ua/laws/show/532/2013 [in Ukrainian].

13. Publications news. (2017). WHO Regional Office for Europe. URL: http://www.euro.who.int/ en/home

14. World Programme of Action for Youth. (2019). Department of Economic and Social Affairs Youth. URL: https://www.un.org/development/desa/youth/world-programme-of-action-for-youth.html

15. Youth 2030 the United Nations Youth Strategy. (2019). Envoy on Youth. URL: https://www.un.org/youthenvoy/2013/08/unesco-united-nations-educational-scientific-andcultural-organization/ 